\title{
Siliceous microfauna in waters beneath Antarctic sea ice
}

\author{
Joseph J. Morley and Jeanne C. Stepien \\ Lamont-Doherty Geological Observatory of Columbia University, Palisades, New York 10964, USA
}

\begin{abstract}
Plankton tows sampling various water depths beneath Antarctic sea ice recovered a high proportion of the cold water assemblage of Radiolaria present in Recent surface sediments underlying these waters. Of the 3 depth intervals sampled, the highest abundances of polycystine Radiolaria were collected in vertical tows from the upper $100 \mathrm{~m}$. Phaeodarian radiolarians occupy a slightly deeper habitat in ice-covered waters with highest concentrations occurring in tows sampling depths between 100 and $200 \mathrm{~m}$. The water structure at the ship station where the highest numbers of polycystine radiolarians were collected was unique in that it consisted of an entrained warm cell of Weddell Deep Water surrounded by cold Weddell Deep Water.
\end{abstract}

\section{INTRODUCTION}

It has been known for some time that siliceous microfauna are capable of living under sea ice in the Arctic (Hülsemann, 1963; Tibbs, 1967). Until recently, however, very little was known about radiolarian abundance and distribution in ice-covered Antarctic waters. Samples taken during the recently completed Weddell Polynya Expedition permit examination of the late winter/early spring radiolarian population living beneath Antarctic sea ice. As the sampling platform for this joint US-USSR expedition, R/V 'Mikhail Somov' remained within the Antarctic ice field from the last week in October through the second week in November 1981. During this time, various physical, biological and atmospheric measurements were taken along a transect in the Atlantic sector of the Antarctic Ocean which extended nearly $600 \mathrm{~km}$ within the sea ice. This report summarizes the radiolarian analyses from plankton-tow samples, comparing faunal abundances with those reported from the open ocean as well as with fauna preserved in the underlying Recent surface sediments.

\section{METHODS}

Radiolaria were collected at 14 stations using $75 \mathrm{~cm}$ diameter, 64 micron-mesh plankton nets equipped with flow meters and rigged for opening and closing.
The nets were vertically towed over 3 depth intervals: 0 to $100 \mathrm{~m}, 100$ to $200 \mathrm{~m}$ and 1,000 to $2,000 \mathrm{~m}$. Because of malfunctions in net operation and/or flow meters at several of these stations, this report is limited to describing the radiolarian fauna in tows from only 8 of the 14 stations.

Initial sample preparation consisted of splitting the sample using a plankton splitter into $1 / 8$ to $1 / 2$ portions of the whole, based on the radiolarian density in each sample. After rinsing the split of the total sample through 250 and 63 micron sieves, the residue was placed in $35 \%$ hydrogen peroxide and put in a $60^{\circ} \mathrm{C}$ oven for $24 \mathrm{~h}$. This oxidation process removed all organic material from the siliceous skeletons. Hydrochloric acid ( $37 \%$ solution) was added to dissolve all calcareous organisms. After a final rinsing in distilled water, the entire residue was mounted on glass slides. Complete specimens ( $>50 \%$ of skeleton intact) belonging to the 2 major groups of Radiolaria (Phaeodaria and Polycystine) were identified and counted on each slide. Phaeodarian (tripylean) skeletal material differs from that of polycystine radiolarians in that it is composed of a combination of organic substances and silica rather than entirely of amorphous silica. No attempt was made to distinguish between specimens which had been living and those which were dead when collected. Species' counts were converted to number of individuals per cubic $m$ of water filtered by the net (ind $\mathrm{m}^{-3}$ ). 


\section{RESULTS AND DISCUSSION}

Station number (CTD), water depth sampled and calculated values (ind $\mathrm{m}^{-3}$ ) for Polycystines and Phaeodaria for each of the tows are shown in Table 1. Tows taken at Ship Station 36,37 sampled plankton at the sea-ice edge, whereas, the remaining 11 tows sampled plankton at various sites within the Antarctic sea ice (for location of ship (CTD) stations see Fig. 1 in Marra and Boardman, 1984). The number of polycystine Radiolaria in samples collected between 0 and $100 \mathrm{~m}$ ranged from 20 to 154 ind $\mathrm{m}^{-3}$. In the nets towed from 100 to $200 \mathrm{~m}$ depths, the number of polycystine radiolarians varied between 9 and 69 ind $\mathrm{m}^{-3}$. In the deep tows $(1,000$ to $2,000 \mathrm{~m})$, polycystine radiolarian abundances of 8 and 18 ind $\mathrm{m}^{-3}$ were measured. These values are an order of magnitude lower than those reported for plankton-tow data over similar depth intervals from transects across the equatorial Pacific (Petrushevskaya, 1971; Renz, 1976) and the Gulf Stream off Florida (Casey et al., 1979). However, they are similar to radiolarian abundances calculated in samples collected from the central portion of the North Atlantic subtropical gyre (Casey et al., 1979) and the North Pacific (Kling, 1979).

Examination of the Weddell Polynya Expedition data from ship stations where plankton tows from both 0 to 100 and 100 to $200 \mathrm{~m}$ were taken shows that greater numbers of polycystine radiolarians were recovered in tows from the upper $100 \mathrm{~m}$ than from the 100 to $200 \mathrm{~m}$ interval. Whether living in waters covered by sea ice (this study) or in the open ocean (Petrushevskaya, 1971; Renz, 1976; Casey et al., 1979; Kling, 1979), polycystines occur in highest concentrations in the upper 100 to $150 \mathrm{~m}$ of the water column.

The highest number of polycystine radiolarians occurred in a plankton tow which sampled the interval between 0 and $100 \mathrm{~m}$ at Ship Station 27,28. Of the 7 ship stations where siliceous plankton were collected beneath the sea ice, this station was the only one to overlie a warm cell of Weddell Deep Water (WDW) within the Weddell cold regime (Fig. 1). As reported by Gordon and Huber (1984), the water in this cell is warmer, saltier, denser and has a higher oxygen content than water from corresponding depths at the other 6 ship stations. The top of the pycnocline is also shallower in this warm cell compared to its position in the surrounding colder WDW. It has been proposed (Gordon and Huber, 1984) that these warm WDW cells are created at the frontal zone separating warmer WDW inflow from colder WDW outflow. Unfortunately, no radiolarian samples were collected at other ship stations where cells of warmer WDW were detected (e.g. Ship Station 32) so we are unable to determine if higher concentrations of polycystine radiolarians were present at these stations as well. Nevertheless, these initial results indicate that polycystine radiolarians inhabit the warmer, saltier, and more oxygenated waters of the warm WDW at higher abundance levels than in the surrounding cold WDW.

The same polycystine radiolarian species were typically present in the 0 to $100 \mathrm{~m}$ and 100 to $200 \mathrm{~m}$ intervals at all seven ship stations where tows from these specific depths were made. Spongotrochus glacialis Popofsky is the most abundant species in samples from the upper $100 \mathrm{~m}$ interval and from 100 to $200 \mathrm{~m}$. It is followed in abundance at these levels by Antarctissa denticulata Ehrenberg, Lithelius nautiloides Popofsky and Triceraspyris antarctica Haeckel. All 4 species are present in lower concentrations in tows from 100 to $200 \mathrm{~m}$ than from 0 to $100 \mathrm{~m}$. Plankton-tow samples over comparable water-depth intervals beneath the Arctic sea ice also contain $S$. glacialis as the most abundant polycystine radiolarian (Huilsemann, 1963; Tibbs, 1967). In the 2 deep tows $(1,000$ to $2,000 \mathrm{~m})$ from the Antarctic data set, Spongurus pylomaticus Riedel and $S$. glacialis occur in higher concentrations than any other polycystine radiolarians.

With the exception of the ice-edge station (Ship

Table 1. Abundance of phaeodarian and polycystine radiolarians in Weddell Polynya Expedition plankton samples, expressed as numbers of individuals $\mathrm{m}^{-3}$ of filtered water

\begin{tabular}{|c|c|c|c|c|c|c|}
\hline \multirow{2}{*}{$\begin{array}{l}\text { Ship } \\
\text { station }\end{array}$} & \multicolumn{2}{|c|}{$0-100$} & \multicolumn{2}{|c|}{$\begin{array}{c}\text { Sample depth }(\mathrm{m}) \\
100-200\end{array}$} & \multicolumn{2}{|c|}{$1000-2000$} \\
\hline & Phaeodaria & Polycystines & Phaeodaria & Polycystines & Phaeodaria & Polycystines \\
\hline 7,8 & 33 & 20 & 35 & 9 & & \\
\hline 9,10 & 29 & 22 & & & & \\
\hline 22,25 & & & & & 4 & 18 \\
\hline 27,28 & 41 & 154 & & & & \\
\hline 29,30 & 23 & 99 & 132 & 69 & & \\
\hline 31 & 24 & 62 & 101 & 24 & & \\
\hline 34 & 11 & 49 & 21 & 25 & & \\
\hline 36,37 & 76 & 108 & 70 & 68 & 6 & 8 \\
\hline
\end{tabular}




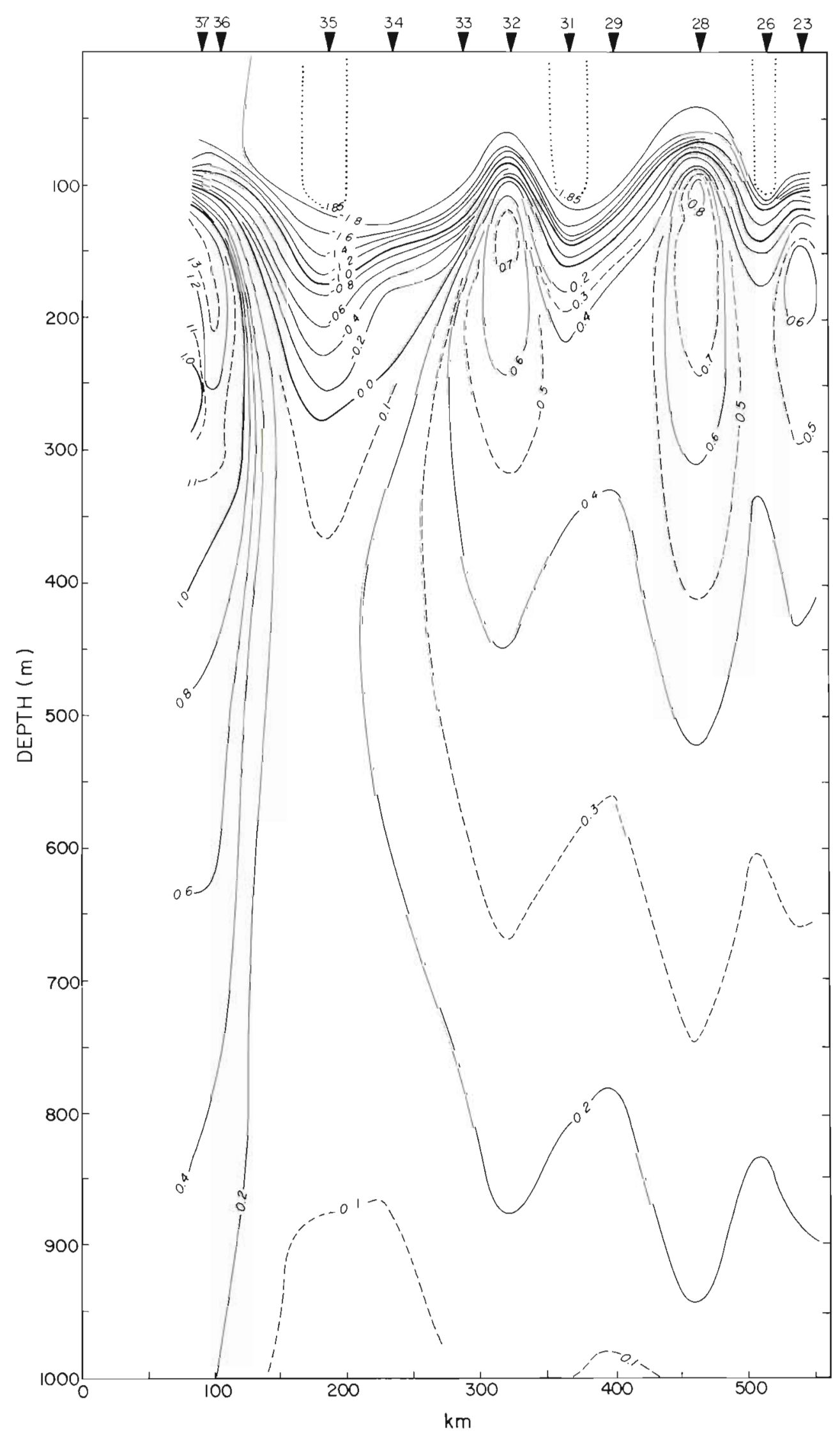

Fig. 1. Potential temperature section compiled from hydrographic stations occupied during exit transect from Antarctic pack ice. Black arrows: location of individual CTD stations along transect 
Station 36,37), phaeodarians occur in higher abundances in tows from 100 to $200 \mathrm{~m}$ than from 0 to $100 \mathrm{~m}$ when comparing results from ship stations where plankton tows from both 0 to $100 \mathrm{~m}$ and 100 to $200 \mathrm{~m}$ were taken. Examination of individual phaeodarian abundances in the samples taken within the Antarctic sea ice shows that Challengeron bicorne Haecker is the most abundant species in tows sampling depths between 0 and $100 \mathrm{~m}$ and between 100 and $200 \mathrm{~m}$. In all 3 tows at the ice-edge station, Protocystis harstoni Murray occurs in higher concentrations than any other Phaeodaria. Higher concentrations of phaeodarians compared to polycystine radiolarians were encountered in the upper $100 \mathrm{~m}$ at the 2 ship stations sampled on the poleward transect (Ship Stations 7,8 and 9,10), whereas, polycystine abundances were higher than phaeodarian radiolarians in tows sampling the upper $100 \mathrm{~m}$ at all ship stations on the northward leg of the expedition (Ship Stations 27,28 through 36,37).

We compared the polycystine radiolarian fauna in the Antarctic plankton tows with the fauna in Recent surface-sediment samples from the Atlantic sector of the Antarctic Ocean south of $55^{\circ} \mathrm{S}$. Five of the 6 species that dominate the Antarctic radiolarian cold water (polar) assemblage defined by Lozano and Hays (1976) from factor analysis of surface-sediment samples in the Antarctic and subantarctic are also present in the plankton in relatively high abundances. Only 1 of the 7 species that show the greatest affinity for the warm water (subantarctic) assemblage defined by Lozano and Hays, however, was collected in our plankton tows. This indicates that the occurrence of most of the members of the warm water assemblage in Antarctic waters may be limited to times of the year other than late winter or early spring when the water properties are more favorable, or that these species were in such low abundances in the Antarctic waters in October and November that they eluded the plankton nets and consequently were not observed in our samples.

\section{CONCLUSIONS}

Although radiolarian abundances in waters beneath Antarctic sea ice are not as high as those from highly productive regions of the open ocean, they are similar to those in less productive waters of the central North Atlantic and North Pacific. The highest concentrations of polycystine radiolarians in the ice-covered Antarctic waters appear to be related to a warm cell of WDW which had been trapped in the surrounding colder WDW. The majority of polycystine species captured in the plankton tows correspond with those which compose the cold water assemblage in the surface sediments underlying the survey area. In the upper $200 \mathrm{~m}$ of water beneath Antarctic sea ice, polycystine radiolarians occur in the highest concentrations between 0 and $100 \mathrm{~m}$, whereas, phaeodarian radiolarians are most abundant in the interval between 100 and $200 \mathrm{~m}$.

Acknowledgements. We thank our fellow WEPOLEX members and N. R. Swanberg for critically reviewing this manuscript and offering helpful comments. Data shown in Fig. 1 were provided by A. L. Gordon and B. A. Huber. J. J. M. thanks A. Pesanell for her laboratory assistance. This research was directly supported by National Science Foundation grants DDP80-08011 and OCE79-24563 to Lamont-Doherty Geological Observatory. Lamont-Doherty Geological Observatory of Columbia University Contribution No. 3688

\section{LITERATURE CITED}

Casey, R., Spaw, J. M., Kunze, F., Reynolds, R., Duis, T., McMillen, K., Pratt, D., Anderson, V. (1979). Radiolarian ecology and the development of the radiolarian component in Holocene sediments, Gulf of Mexico and ajdacent seas with potential paleontological applications. Gulf Coast Ass. Geol. Soc. Trans. 29: 228-239

Gordon, A. L., Huber, B. A. (1984). Thermohaline stratification below the Southern Ocean sea ice. J. geophys. Res. 89: $641-648$

Hülsemann, K. (1963). Radiolaria in plankton from the Arctic drifting station $T-3$, including the description of three new species. Arctic Inst. North Am., Tech. Paper 13, p. 1-52

Kling, S. A. (1979). Vertical distribution of polycystine radiolarians in the central North Pacific. Mar. Micropaleontology $4: 295-318$

Lozano, J. A., Hays, J. D. (1976). Relationship of radiolarian assemblages to sediment types and physical oceanography in the Atlantic and western Indian Ocean sectors of the Antarctic Ocean. In: Cline, R. M., Hays, J. D. (ed.) Investigation of late Quaternary paleoceanography and paleoclimatology. Mem. geol. Soc. Am. 145: 303-336

Marra, J., Boardman, D. C. (1984). Late winter chlorophyll a distributions in the Weddell Sea. Mar. Ecol. Prog. Ser. 19: 197-205

Petrushevskaya, M. G. (1971). Spumellarian and nassellarian radiolaria in the plankton and bottom sediments of the central Pacific. In: Funnell, B. M., Riedel, W. R. (ed.) The micropaleontology of oceans. Cambridge University Press, Cambridge, England, p. 309-318

Renz, G. W. (1976). The distribution and ecalogy of Radiolaria in the central Pacific plankton and surface sediments. University of California Press, Berkeley, California, p. $1-267$

Tibbs, J. F. (1967). On some planktonic Protozoa taken from the track of drift station ARLIS I, 1960-1961. Arctic Inst. North Am. 20: 247-254 